\title{
THE PRECONDITIONS FOR THE EMERGENCE AND DRIVERS OF MARKETPLACES DEVELOPMENT IN E-COMMERCE
}

\author{
Nina Pavlishyna ${ }^{1}$, Liudmyla Kot ${ }^{2}$
}

\begin{abstract}
The virtual environment is getting closer to the person. From an information field designed for information exchange, it is transformed into a full-fledged business environment. A significant number of business processes today are conducted via the Internet, which necessitates an alternative approach to the organization of key aspects of management.

The rapid development of technology leads to the emergence of novel forms of interaction between contractors, increases their range, involves not only manufacturers and buyers but also other companies, including logistics, banking, brokerage, into the processes, which leads to increased overall business activity.

Intensification of business interaction leads to the emergence of new business models. In particular, the current stage is characterized by the transition from online stores to marketplaces, which are full-fledged trading platforms where there is supply and demand.

The article examines the prerequisites for the emergence of marketplaces as one of the tools of digital marketing and provides a brief description of them. Thus, the analysis of the level of Internet penetration in the world and in Ukraine confirmed the course of digitalization of society. The study of analytical reports made it possible to confirm the rapid spread of access to the network and the involvement in the virtual environment of an increasing number of users in different age groups and from different regions. Such penetration allows to take into account globalization, eliminate barriers to access, and ensure greater involvement of counter-parties in market processes taking place in the network.

The analysis of e-commerce indicators has confirmed the assumption that the intensity of use of e-commerce services correlates with the level of the Internet penetration.

Joint analysis of the level of the Internet penetration and e-commerce data has revealed the key characteristics of the modern user of the network as a buyer. In particular, to outline his or her behavioral and consumer preferences, note the attitude to advertising, the desired level of service and the need to ensure data confidentiality. Drawing up a portrait of the consumer allows to understand his or her network activity and take it into account in the formation of communication, sales organization and product promotion. Tracking consumer activity also permits making a modeling impact on it, pushing the buyer to certain actions from information to purchase.

Assessment of the current situation in Ukraine allows to predict a corresponding increase in activity in the field of electronic sales. The various business models used in e-commerce are considered, and their functionality is depicted. The key factors that led to the emergence of marketplaces are highlighted and the impact of each of them is considered separately. The classification of marketplaces according to different classification features is given and the advantages of use are outlined. The tendency to emergence of new formats of marketplaces and expansion of their functionality is revealed, which significantly increases the possibilities of users from the position of organization of work and ensuring circulation of information flows. The main drivers of formation of marketplaces in the world and Ukraine are singled out. The vector of their development is traced.
\end{abstract}

Key words: Internet, e-commerce, e-trade, consumer, marketplace.

JEL Classification: L81, M39

\footnotetext{
Corresponding author:

1 "Zaporizhzhia Polytechnic" National University, Ukraine.

E-mail: pavl n m@ukr.net

ORCID: https://orcid.org/0000-0001-7715-9202

${ }^{2}$ Taras Shevchenko National University of Kyiv, Ukraine.

E-mail: lyuda.kot@gmail.com

ORCID: https://orcid.org/0000-0002-7142-8149
} 


\section{Introduction}

The world is becoming digital. A significant number of companies operate entirely virtually or use elements of e-commerce. The more developed the country's economy, the larger the volume of the electronic market. This tendency is observed in the United States, Western Europe and Asia, which have robust economies.

One of the promising areas of development is the use of the Internet. Today it is a changing field, which is characterized by a high level of novelty, manufacturability, information saturation and unlimited possibilities.

The high level of the Internet penetration, the rapid development of e-commerce has led to the involvement of enterprises in the field of online commerce. It is very difficult to assess the market comprehensively due to the blurring of the boundaries between offline and online. The penetration of the Internet has also changed the behavior of consumers who spend more and more time online, use mobile devices for quick access, need personalized service and strive to maintain confidentiality. Knowing the needs of consumers, it is possible to offer them a high level of service, better supply and adjust communications.

The objective feature of the Internet is that from the information field it has altered in a tool of dialogue between the company and contractors, has become a means of influencing the consumer, building a more personalized relationship with him or her. The virtual environment provides equal opportunities, small businesses can compete for the consumer with large ones. This is facilitated by the emergence and rapid development of aggregate trading platforms - marketplaces, through which the volume of trade is growing very rapidly. Changing the business model and moving to marketplaces provides significant benefits for entrepreneurs, including the ability to start quickly with low costs and access to a circle of loyal customers. The consumer can choose from a variety of offers more attractive terms and price.

The marketplace model is not limited to trade. It is relevant for many industries, as it expands the range and increases the visibility of the brand online. Large retailers, logistics and postal operators, financial and IT companies are moving to the marketplace format. Some online stores are also moving to the marketplace model, providing additional opportunities for business development, expanding channels of interaction with the audience.

Noting the tendency to increase the influence of marketplaces on the promotion and sale of goods, the presence of their varieties should be noted. The entrepreneur has the opportunity to choose a specialized platform, focusing on a particular segment, or choose a universal marketplace and expand its presence.

Isolation of marketplace development drivers allows determining the factors influencing their development at the moment. Undoubtedly, new ones will be added to the outlined drivers, which will help accelerate the growth of demand for the analyzed business model, which permits predicting the development of marketplaces in the future.

\section{Literature review}

The transition to such a business model of cooperation between the seller and consumer as the marketplace has recently begun and is gradually happening. Therefore, the reasons for their emergence and drivers of development have recently become relevant for research among the leading scientists. Today it is a research area that has not been analyzed in detail. That is, there is no theoretical basis on which it is possible to investigate the phenomenon of the marketplace. Like most marketing phenomena, the study of marketplaces is primarily an applied field, and the lack of unambiguous statistics has led to the use of the following sources in the study:

- data of world and Ukrainian research organizations concerning the level of the Internet penetration: (Ukrainian Internet Association), (Factum Group Ukraine), Wearesocia (Think Forward 2020). A generalized portrait of a modern buyer is formed on the basis of the database;

- statistical data and reports of global organizations that record, process and analyze (including comparative by country) statistical information on the state of e-commerce: (Eurostat), Organization for Economic Co-operation and Development (OECD), State Statistics Service of Ukraine (Ukrstat) and (National Bank of Ukraine);

- data from independent companies on the state of e-commerce are presented by: Wearesocial (Kemp, 2020), Growth from Knowledge (GfK), Emarketer (Lipsman, 2020), Digitalcommerce360 (Fareeha, 2019), (Ukrainian Retail Association);

- information of companies of the Ukrainian e-commerce market, provided on the official pages in the form of reports, reviews or interviews: (Hubber), (EVO);

- publications in journals related to the state of e-commerce in Ukraine and the world: Clement (2019), Prosovych \& Botsman (2018), Hlinenko \& Daynovskyy (2018).

\section{Problem statement}

The purpose of the article is to identify the prerequisites for the emergence of marketplaces and analysis of drivers for their development. Achieving the goal demands solving such tasks as assessing the level of Internet penetration, evaluation of the current state of the e-commerce market, analysis of consumer behavior, characterization of business models used in the virtual environment, classification of marketplaces. 
The methodological and theoretical basis of the study is the use of a systemic approach to studying of the current state and trends of the e-commerce market; historical-logical method is used to study the prerequisites for the formation of marketplaces and the selection of drivers for their development; sampling method, grouping, statistical comparison are applied when analyzing the activities of marketplaces; graphic is used for a visual representation of the results; integrated approach and logical generalization are to form a portrait of the consumer in a virtual environment and provide a classification of marketplaces. Symbiosis using these methods allows to provide a comprehensive nature in the subject's study and solving problems.

\section{Problem solving}

Modern marketing uses the concept "e-commerce" to describe economic relations involving the Internet, which has the following definition:

- sale or purchase of a good or service, conducted over computer networks by methods specifically designed for the purpose of receiving or placing orders (OECD, p. 4);

- the sale or purchase of goods or services, whether between businesses, households, individuals, or private organizations, through electronic transactions conducted via the Internet or other computer-mediated (online communication) communication. The term covers the ordering of goods and services which are sent over computer networks, but the payment and the ultimate delivery of the goods or service may be conducted either on- or offline (Eurostat).

One of the most important components of e-commerce is E-Trade, which is developed according to market laws, creates a competitive environment, and has its own unique formats. Marketplaces are among the formats that are unique to the virtual environment.

A marketplace is a form of product sales, which is a trading platform on the Internet, which facilitates online meetings between the seller and potential buyer and their cooperation.

The idea of the marketplace received a new round of development in the 2000s after the publication of Chris Anderson's book “The Long Tail: Why the Future of Business is Selling Less of More”. Anderson (2008) argues that the key to increasing sales is a wide assortment. That is, the more products of different categories will be offered by the store, the greater is the probability of a sale. Today, businesses are starting to go to marketplaces, because these are new opportunities to increase sales. This trend applies even to large and already popular online stores with an established image, such as Amazon.

The marketplace is a combination of three components - a shop window (product catalog), a consumer's office (identical to an online store), and a seller's office (through which goods are placed and analytics are tracked). That is, the classic marketplace is an aggregate that accepts orders from the buyer and sends it to the seller, performing an intermediary function.

According to the author, the development of marketplaces is caused by two key factors:

- first, by increasing the level of the Internet penetration, which makes the buying and selling process easier;

- second, by the strengthening of activity in the e-commerce market, the emergence of new software that opens up new opportunities for the sale and promotion of goods and allows to collect more relevant information about the consumer.

The combined effect of these factors has changed consumer behavior, for that reason they should be analyzed in more detail.

A new environment for economic activity in the online space is formed and developed due to the wide Internet penetration. The Internet is a marketing environment that demonstrates the most dynamic development. Today, it is a multibillion-dollar business, a platform for promotion and sales, which attracts more and more companies and consumers, changing consumer behavior and trading methods. It can be assumed that the intensity of use of e-commerce services (including e-trade) correlates with such an indicator as the number of the Internet users in the country.

In Digital Around the World in April 2020 (Kemp, $2020)$, it was reported that the number of people worldwide using the Internet in April 2020 increased to 4.54 billion, an increase of $7 \%$ (298 million new users) compared to last year. The map of the world by the level of Internet penetration (Ukrainian Retail Association) is shown in Figure 1.

The report (Ukrainian Retail Association) states that the share of those who use the Internet for shopping presents a slightly different picture. There are countries where the share of the Internet users is minimal - only $13 \%$ (the Dominican Republic), and it is significant in other countries $-89 \%$ (UAE). In addition, the figure is constantly changing. In 2018, Sweden was in the first place with a rate of $86 \%$ (in $2019-84 \%$ ). In 2017 (there were only 22 countries in the study), England was ahead with a share of $98 \%$ (in $2019-87 \%$ ). As for Ukraine, according to research companies (Ukrainian Internet Association) and (Factum Group Ukraine) the penetration rate is $71 \%$. At the same time, the Internet penetration rate has increased almost three times over the last ten years and by $10 \%$ over the last year. The surge is caused by the focus of the Government of Ukraine on the deployment of modern infrastructure and digital development technology.

The second factor that led to the emergence of marketplaces is the development of e-commerce, E-Trade in particular. Due to the digital transformation and the rapid development of computer technology, 


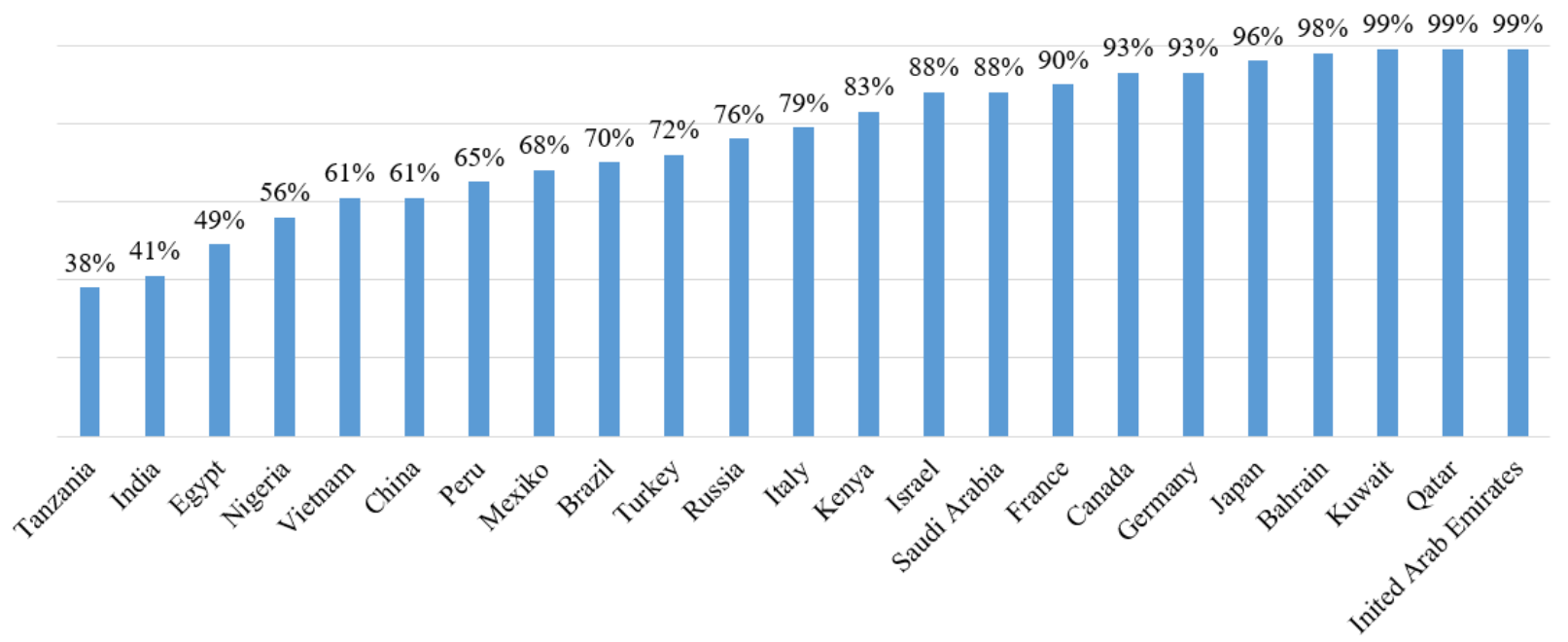

Figure 1. Level of Internet coverage (Ukrainian Retail Association)

consumer behavior is changing and traditional business is gradually moving online.

It is difficult to estimate the indicators of e-commerce development in Ukraine and around the world due to the lack of a single statistical reference. In "A review on measuring digital trade \& e-commerce as a new economic statistics product" it is stated that "little empirical and internationally comparable information currently exists. This has inhibited a full understanding of the scale and policy challenges of digital trade" (OECD). That is, there are significant gaps in the digital trading economy. In addition, the fact that the line between online and offline is blurred prevents the provision of a comprehensive assessment of the e-trade market. The buyer can choose the product online and pick up, and pay for it in a regular store, or vice versa.

This study used a significant amount of marketing information on the current state of e-commerce. As research companies record and process data according to their own methods, it is taken into account that this leads to the "distortion" of statistical data. Therefore, the method of cross-comparison of data will be used to obtain more relevant results.

The global e-commerce market in 2019 grew by $17.9 \%$ and amounted to 3.46 trillion USD, demonstrating a decline in growth dynamics (Figure 2). China and the United States are leaders in e-commerce: they account for about $40 \%$ of the market (Tushin, 2020).

According to eMarketer (Lipsman, 2020) forecasts, the e-commerce market should grow to 3.535 million USD and show growth of $14.1 \%$. Respectively forecasts for other years also need to be revised. This indicates a more dynamic development of e-commerce than experts predict and the difficulty of forecasting for the long term.

It can be claimed that the e-commerce market is growing. The World Retail Congress published a report (Global e-commerce Market Ranking 2019), prepared

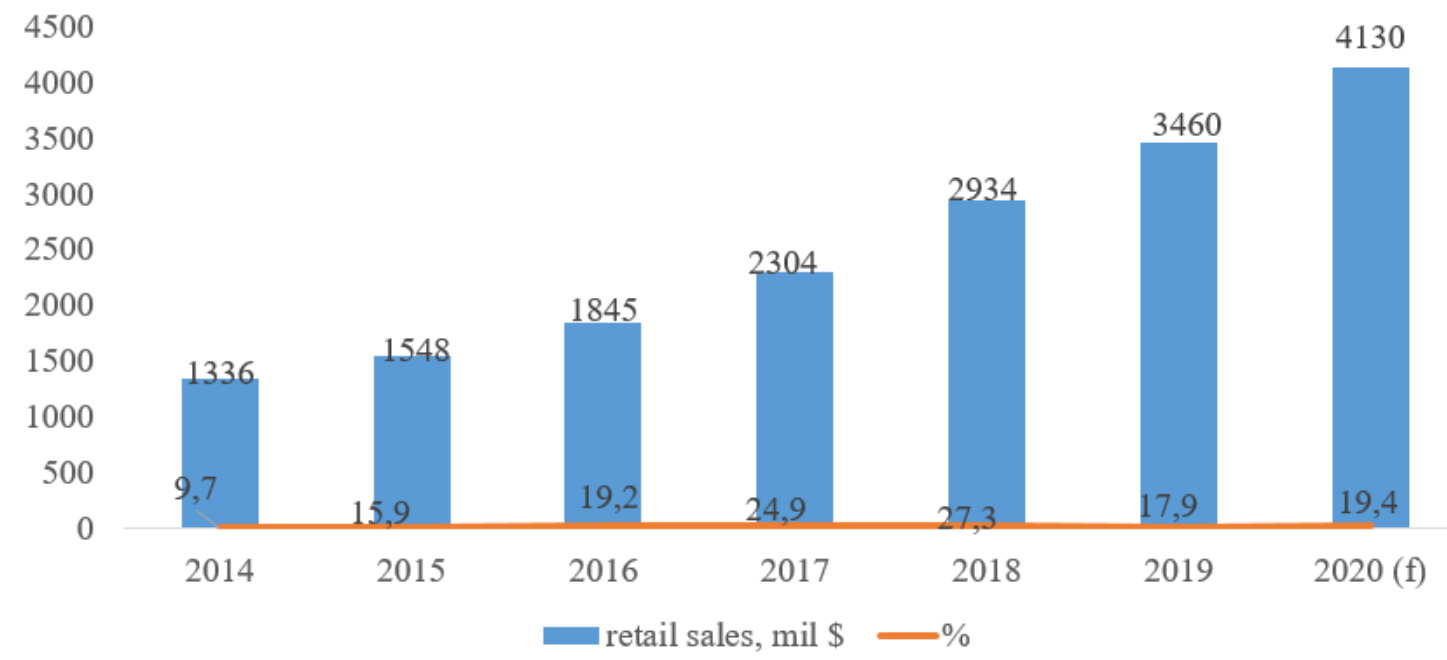

Figure 2. Dynamics of the global e-commerce market (Tushin, 2020) 


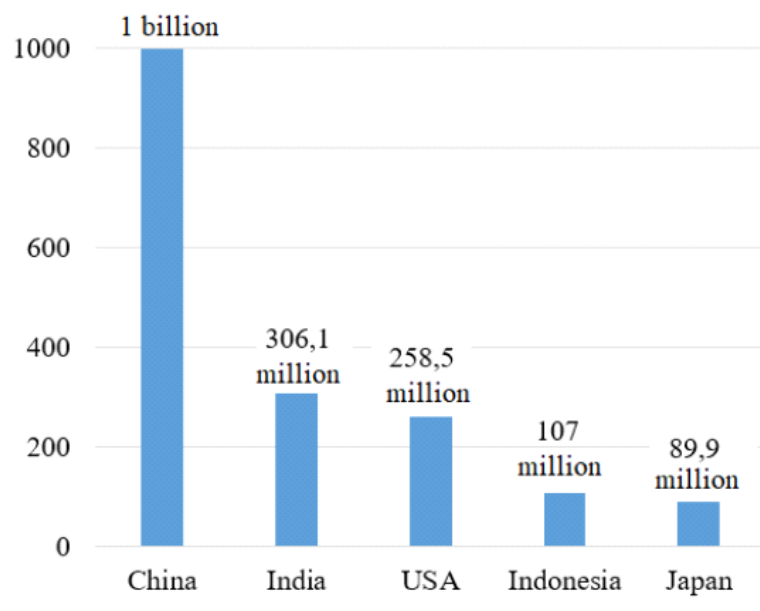

Top 5 markets bytotal number of online shoppers

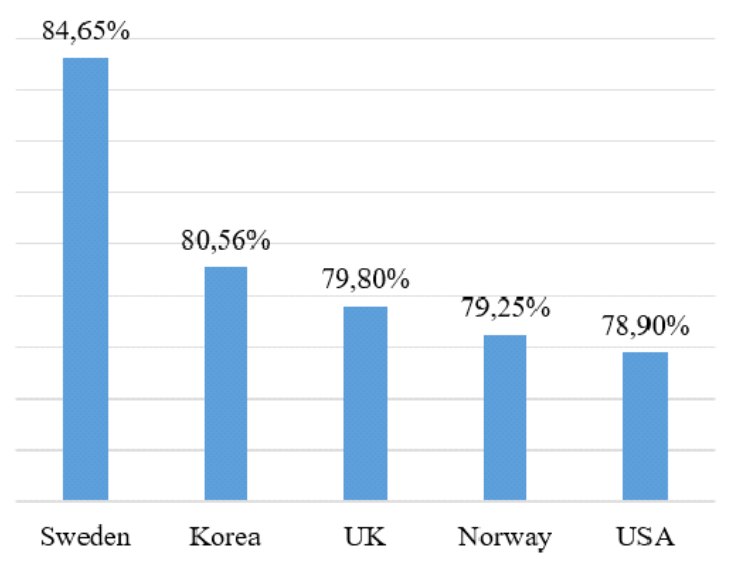

Top 5 markets by number of online shoppers (\% of population)

Figure 3. Number of online shoppers (Global E-commerce Market Ranking 2019)

by eShopWorld, Statista, WorldBank, eMarketer, New Zealand on the total number of online shoppers and percentage of the country's population (Figure 3 ).

Analysts (Ukrainian Retail Association) suppose that a significant part of e-commerce turnover (44\%) in 2020 will be generated in Asia and Oceania. Another $26 \%$ will be provided by North American countries and $22 \%$ by Europe. The minimum share of $1 \%$ is in Africa. More positive indicators are noticed in South America (2\%) and the Middle East (4\%). These data suggest that a high level of the Internet penetration correlates with a high rate of e-commerce, as shown in Figure 2. In this context, eMarketer's forecast for a slowdown in China and India (Cramer-Flood, 2020) is correct.

Penetrating into all spheres of human life, free access to network resources changes consumer behavior. The portrait of the modern consumer is formed according to the data: (The Ukrainian Internet Association), (Ukrainian Retail Association), (Factum Group Ukraine), (National Bank of Ukraine), Digital around the world in April 2020 (Kemp S., 2020), Wearesocia agencies (Think Forward 2020), EVO (EVO), (Hubber), All Internet statistics for 2020 (Sergeeva, 2020), e-commerce Statistics \& the Industry's Vibrant Future (Stevanovic, 2020). The data of the given sources allows to draw conclusions concerning the average user of a network (Table 1).

It should be noted that the E-Trade development rate was influenced by the measures taken by the states caused by COVID-19. Sales figures during the quarantine period compared to the same period in 2019 are shown in Figure 4. As can be seen, almost all countries have experienced a period of trade decline.

At the same time, the number of new stores is actively increasing (Bakharev, 2020), which indicates the reorientation of sellers to the online environment
(Figure 5). According to the Growth Intelligence study (as cited in Skeldon, 2020), in addition to companies that have historically dominated the Internet, new companies have been added, such as pharmacies, food companies, etc.

According to the European Business Association (Small business sentiment is improving), which is conducting research in Ukraine within the Unlimit Ukraine project, the situation is similar. This is evidenced by the number of satisfied with the state of business, which increased significantly (42\% in 2019; $31.6 \%$ in 2018). The index of small business sentiment rose to 3 points (in $2018-2.7$ points). In Ukraine, the e-commerce market is the place that demonstrates the best growth rates, along with India and China. And this is due to a fairly large indicator of the shadow economy (Figure 6).

E-retailers of the world use different business models (Table 2).

At the moment, online stores and marketplaces dominate 31 and $69 \%$ of parcels, respectively (Tushin, 2020). After all, not all sellers in the network are giant companies, small businesses are also actively involved in virtual trade. Thus, in Ukraine, $98.4 \%$ of enterprises engaged in trade through the network belong to the category of "small enterprises" (98.2\% of which are micro-enterprises) (State Statistics Service of Ukraine).

Entering the virtual environment is a new opportunity to increase sales. Although, this trend applies even to large and already popular online stores with an established image, such as Rozetka and Amazon.

The rapid development of marketplaces is evidenced by data (Ukrainian Retail Association):

- all market leaders in the B2C sector have fully or partially become marketplaces; 
Table 1

Characteristics of the average network user

\begin{tabular}{|c|c|}
\hline $\begin{array}{c}\text { User } \\
\text { characteristics }\end{array}$ & Detailed characteristics \\
\hline Personal & $\begin{array}{l}\text { - a representative of the active part of the population ( } 66 \% \text {, people aged } 15-44 \text { years); } \\
\text { - educated ( } 36 \% \text { of users have higher education and another } 40 \% \text { secondary special education); } \\
\text { - average income level ( } 44 \% \text { ) and below-average ( } 40 \%) ; \\
\text { - a user of mobile devices ( } 69 \% \text { use a smartphone, tablet or laptop to access the network), while } 22 \% \text { use a mobile phone only; }\end{array}$ \\
\hline Behavioral & $\begin{array}{l}\text { - buys goods and services online (including online consulting); } \\
\text { - demonstrates a measured approach to digital consumption; } \\
\text { - spends } 6 \text { minutes } 13 \text { seconds every day online. The highest figure is in the Philippines, where consumers are online for } \\
\text { almost } 10 \text { hours a day; } \\
\text { - shops occasionally ( } 78 \% \text { of the Internet users in Ukraine buy only from time to time - this is a significant potential for } \\
\text { growth); } \\
\text { - wants to receive personalized service, short delivery terms, the ability to pay for purchases in national currency, etc. This } \\
\text { indicates a shift in consumer expectations; } \\
\text { - concerned about the issue of confidentiality. } 64 \% \text { of users are concerned about how their personal information will be } \\
\text { used, and } 23 \% \text { will refuse to buy if they need to create a personal profile; } \\
\text { - uses adblocking - } 49 \% \text {; } \\
\text { - aimed at a long search for information. Thus, in } 2019 \text {, only } 2.58 \% \text { of visits to E-commerce pages led to sales, and about } \\
70 \% \text { of all baskets were left without a purchase. } 95 \% \text { of people read reviews, and } 85 \% \text { examine the product online before } \\
\text { buying online; } \\
\text { - focused on environmental protection. Thus, } 33 \% \text { of people buy goods from companies that care about the environment; } \\
\text { - waits for "instant" service. There is a dependence of cancellations of the purchase on the speed of feedback with the } \\
\text { customer: if the seller calls the customer back within } 24 \text { hours, there is an average of } 18 \% \text { cancellations; within } 48 \text { hours, an } \\
\text { average cancellation rate is } 27 \% \text {; within } 72 \text { hours, there is an average of } 41 \% \text { of cancellations; } \\
\text { - prefers to pay by card. Cash on Delivery in the European Union is } 13 \% \text {, in Ukraine, only } 24 \% \text { of all payments were made } \\
\text { by bank cards to pay for goods and services online }\end{array}$ \\
\hline
\end{tabular}

Source: summarized by the author

90

80

70

50

40

30

20

10

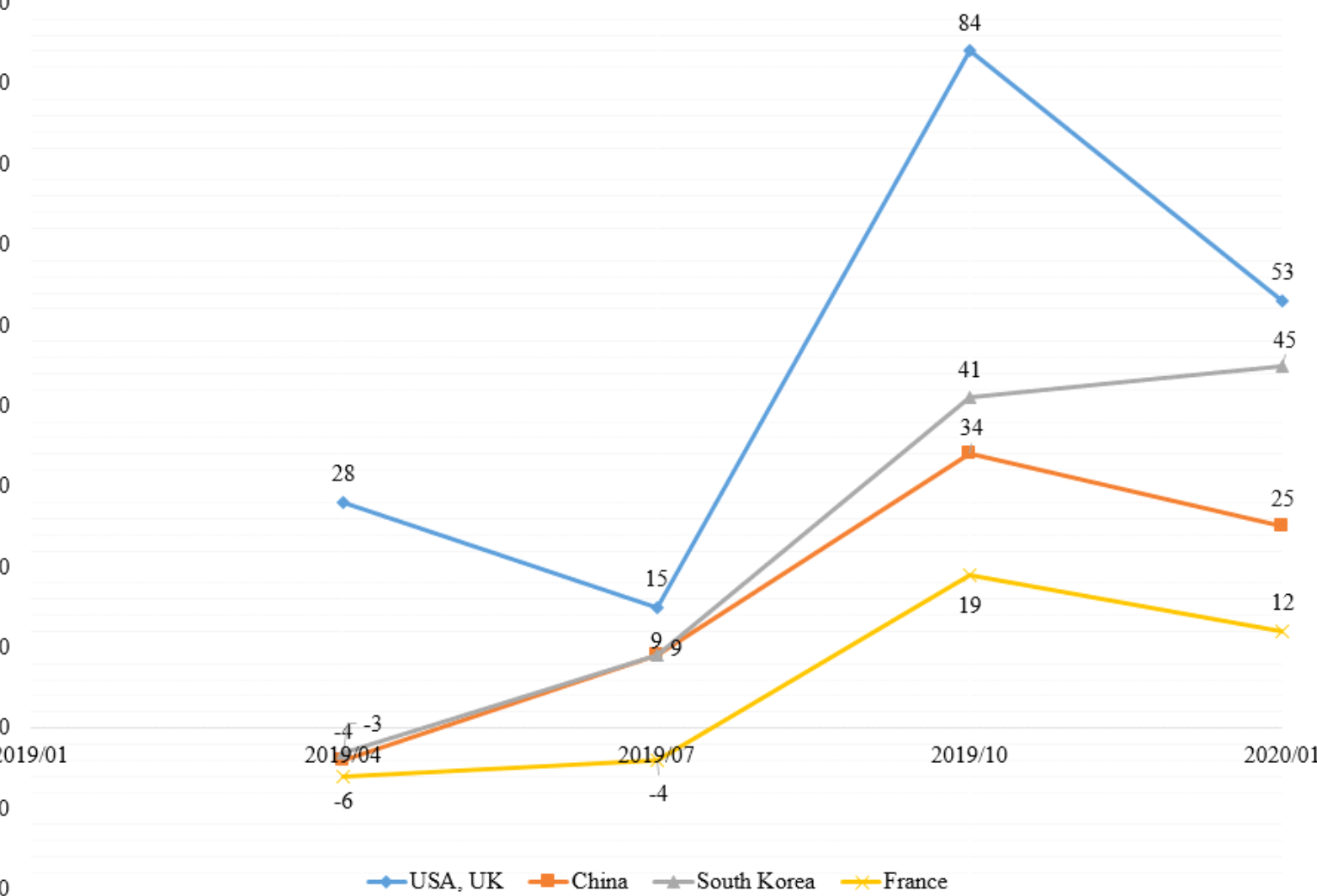

Figure 4. Level of e-commerce in the period of COVID-19 (Ukrainian Retail Association) 


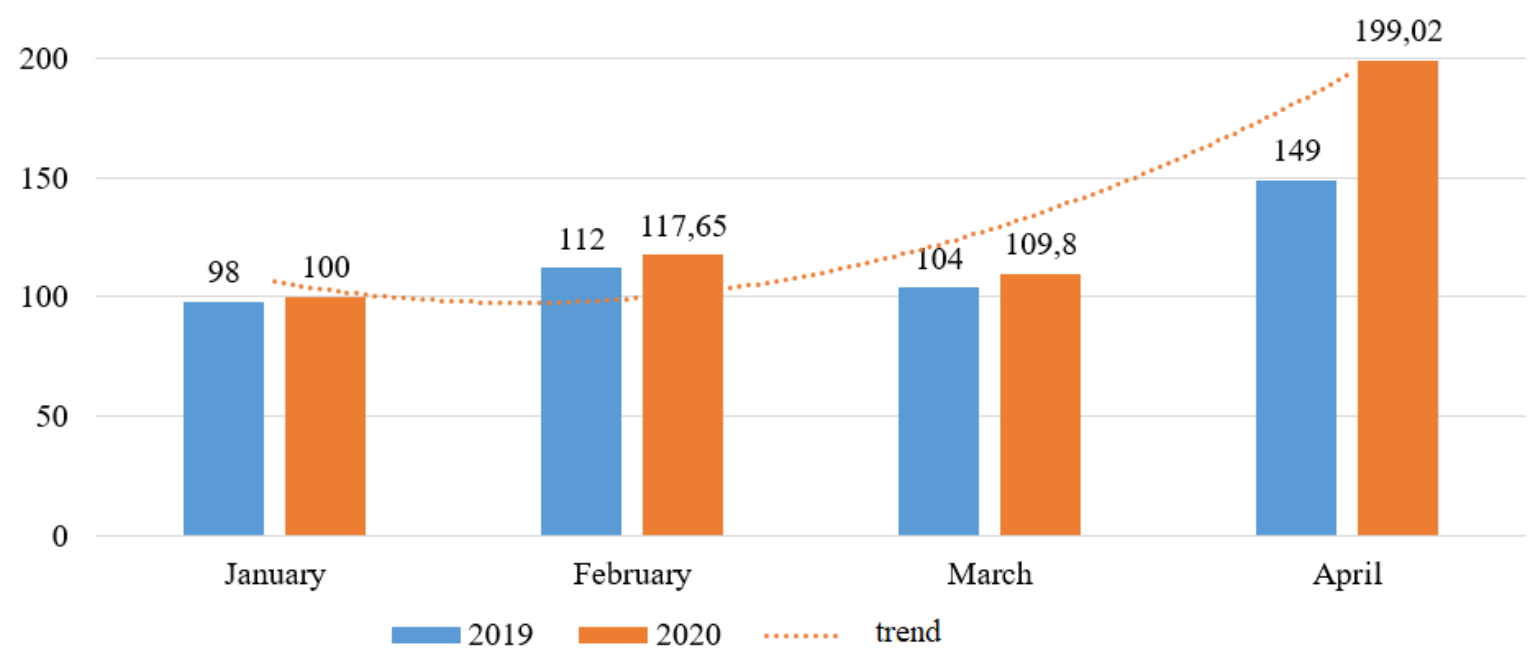

Figure 5. Dynamics of opening new online stores in 2019-2020

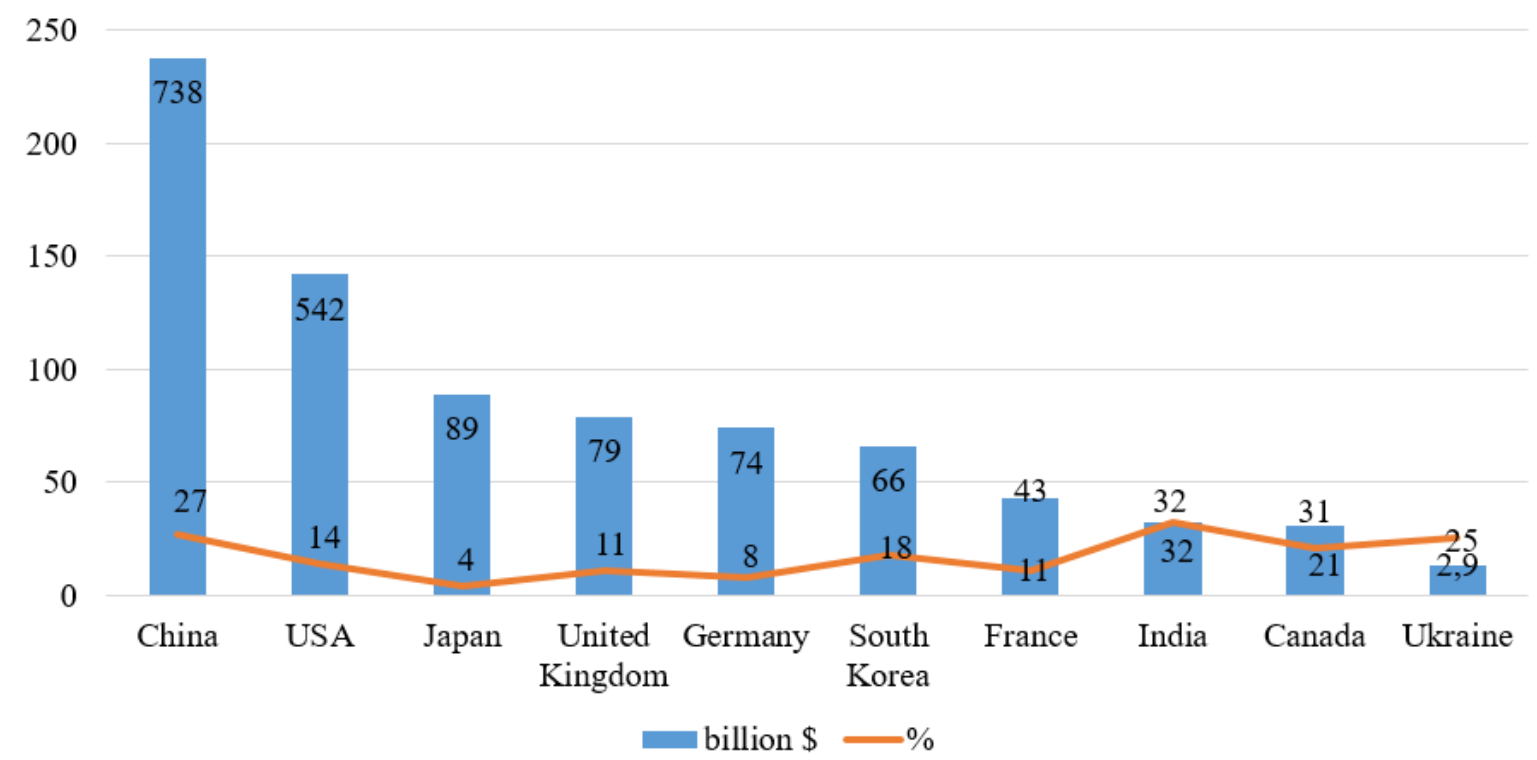

Figure 6. Indicators of global e-commerce

Source: Tushin, 2020; Ukrainian Retail Association

- every fifth online showcase has changed its format to a marketplace;

- every second company from among the TOP-20 that did not become a marketplace left the market.

Marketplaces can be classified on several grounds. Based on the analysis of the work of popular marketplaces, the author proposes a classification, which is demonstrated in Figure 7.

The number of marketplaces of different directions and specializations is constantly increasing. It should be noted that there are no objective statistics on the results of their operation both in the world and in Ukraine. The analysis of marketplaces was based on data (Ukrainian Retail Association), (EVO), (National
Bank of Ukraine), Clement (2019), Coleman (2020), Prosovych \& Botsman (2018), Fareeha (2019), Hlinenko \& Daynovskyy (2018).

The author highlighted the following drivers of marketplace development (Figure 8).

The justification for the choice of drivers discussed above:

- the presence of a loyal audience. A marketplace is a place of the presence of a significant number of visitors loyal to the site. This is facilitated by the publication of the rating of sellers and reviews of cooperation with them. So the seller does not need to spend money on promotion. After analyzing several Ukrainian marketplaces, it was found that one product 
Table 2

Business models of e-commerce

\begin{tabular}{|l|l|l|l|l|}
\hline Business model & Function & Presence & Buyer-seller communication & Example \\
\hline $\begin{array}{l}\text { electronic } \\
\text { bulletin board }\end{array}$ & Placing product ads and contacts & $\begin{array}{l}\text { A significant number of } \\
\text { companies }\end{array}$ & $\begin{array}{l}\text { - mail; } \\
- \text { telephone; } \\
- \text { messengers }\end{array}$ & $\begin{array}{l}\text { Besplatka.ua, } \\
\text { AllBiz }\end{array}$ \\
\hline $\begin{array}{l}\text { electronic } \\
\text { showcase }\end{array}$ & $\begin{array}{l}\text { Placement of information about } \\
\text { the product, its characteristics, } \\
\text { approximate prices. }\end{array}$ & $\begin{array}{l}\text { One company owns an } \\
\text { electronic showcase }\end{array}$ & $\begin{array}{l}\text { - mail; } \\
- \text { telephone; } \\
- \text { messengers }\end{array}$ & $\begin{array}{l}\text { Peugeot, } \\
\text { Motor Sich }\end{array}$ \\
\hline e-shop & $\begin{array}{l}\text { Information placement, the ability to } \\
\text { place an order, pay for goods, track } \\
\text { goods }\end{array}$ & $\begin{array}{l}\text { A wide assortment of one } \\
\text { owner company }\end{array}$ & $\begin{array}{l}\text { - - - -elephone; } \\
- \text { messengers; } \\
\text { - e-shop page }\end{array}$ & $\begin{array}{l}\text { Metro; } \\
\text { Modnakasta; } \\
\text { Leboutique; } \\
\text { Eldorado }\end{array}$ \\
\hline marketplace & $\begin{array}{l}\text { Information placement, the ability to } \\
\text { place an order, choose the method of } \\
\text { delivery, pay for the goods, track the } \\
\text { goods }\end{array}$ & $\begin{array}{l}\text { Wide assortment, many } \\
\text { sellers }\end{array}$ & $\begin{array}{l}\text { - telephone; } \\
\text { - messengers; } \\
\text { - marketplace page with } \\
\text { redirection to the seller's page }\end{array}$ & $\begin{array}{l}\text { Prom.ua } \\
\text { Rozetka.ua (hybrid); } \\
\text { privatmarket.ua; } \\
\text { Allo.ua }\end{array}$ \\
\hline
\end{tabular}

Source: summarized by the author

from a third-party supplier in the shop window gives $3.97-6.07$ visitors without investing in advertising budgets (only SEO);

- geographical unlimitedness. According to the Ukrainian Retail Association, in 2019 Ukrainian buyers visited the following sites (Figure 9). To build the graph, traffic from Ukraine and repeated visits are taken into account. The rate of unique visitors is more accurate, but data is absent. The chart shows that the TOP-10 Ukrainian marketplaces include two of the three most popular marketplaces in the world (Sales on marketplace sites Alibaba, Amazon, eBay accounted for 58\% of global web sales in 2019 (Fareeha, 2019);

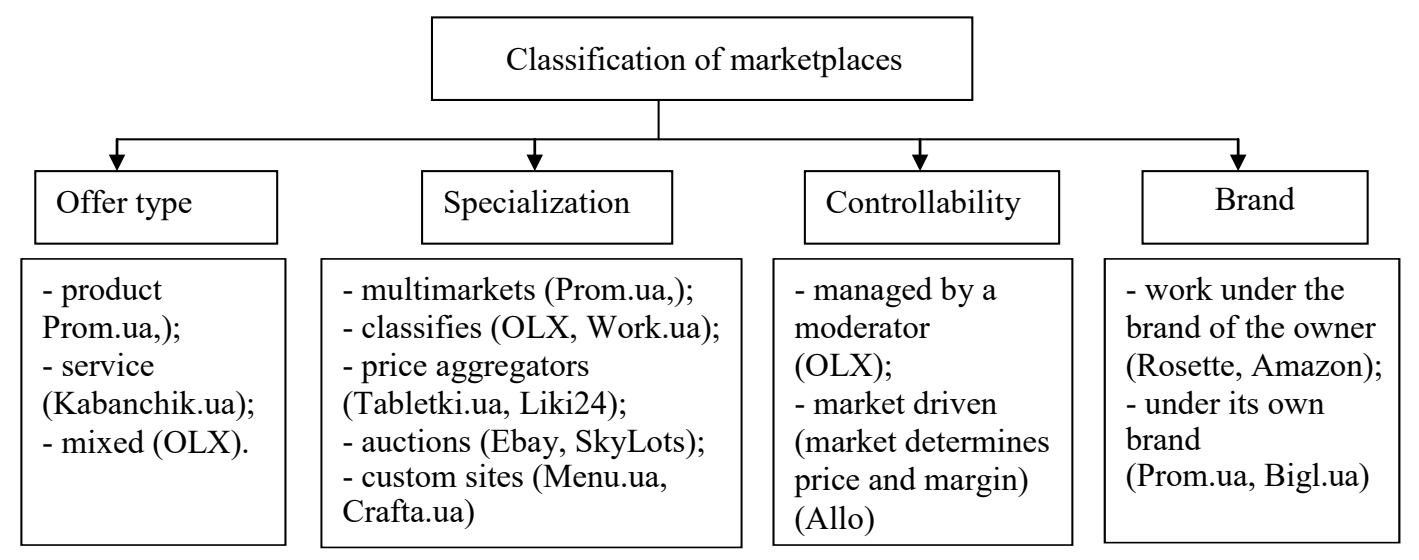

Figure 7. Classification of marketplaces

Source: generalized by the author

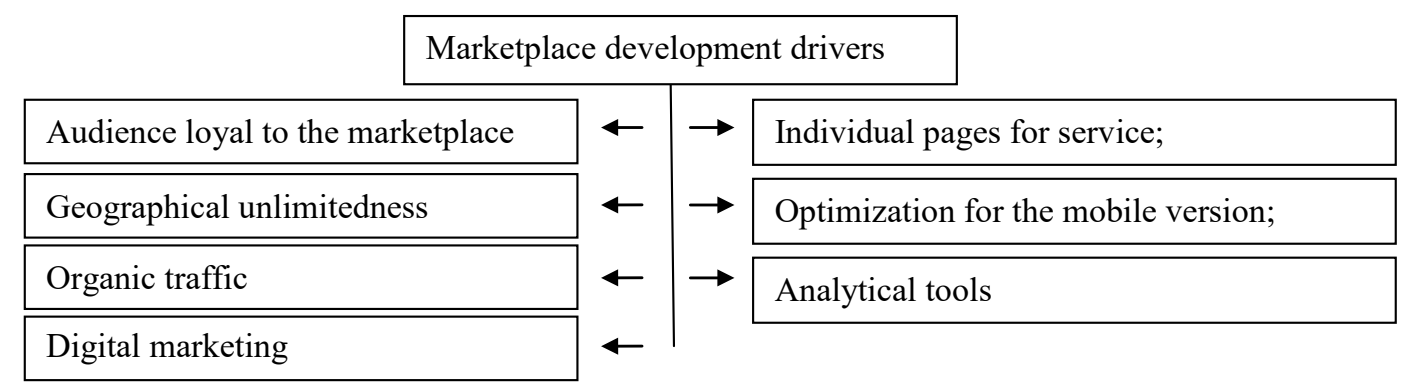

Figure 8. Marketplace development drivers 


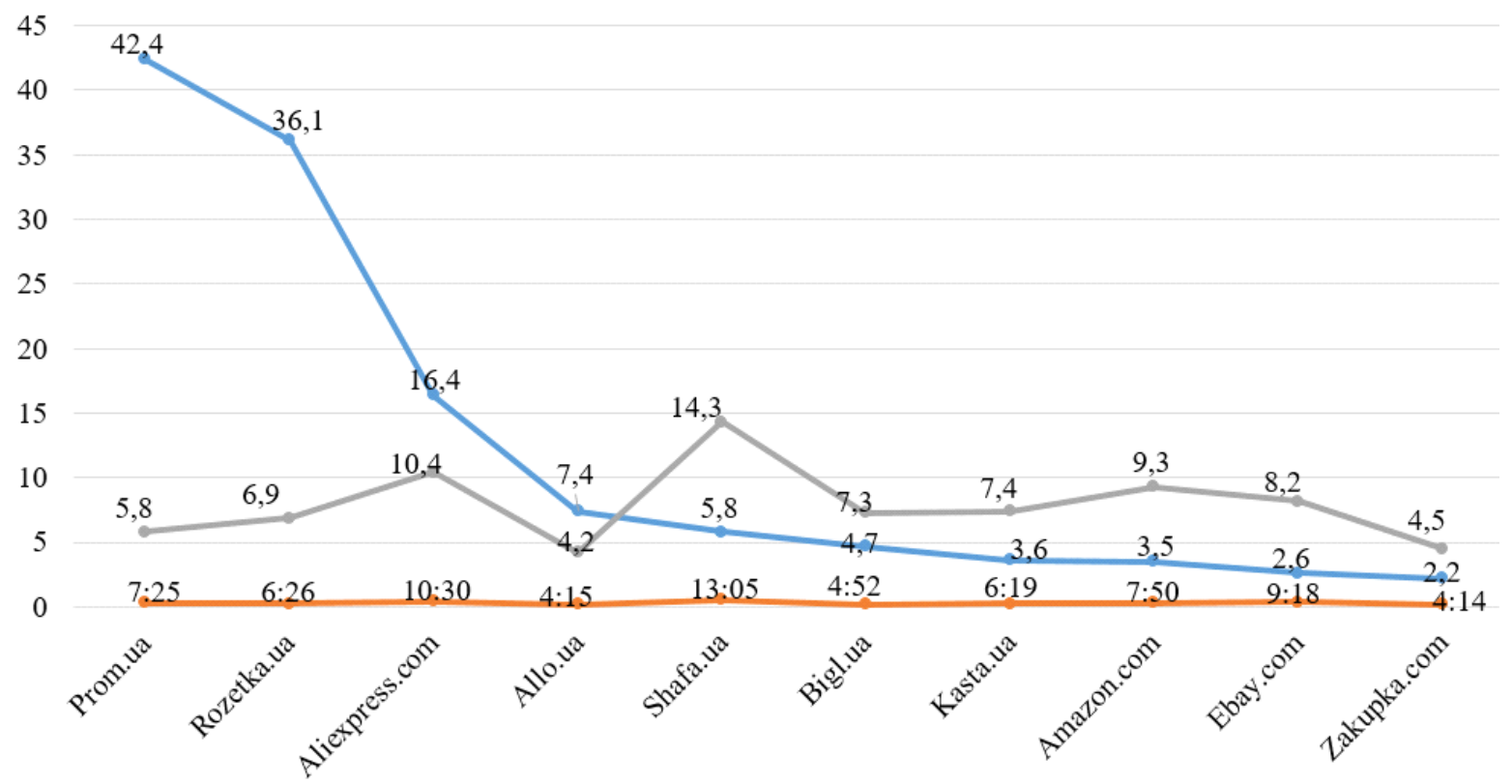

Figure 9. TOP-10 marketplaces in Ukraine (Ukrainian Retail Association)

- wide assortment with the ability to filter by parameters. This leads to a significant increase in organic traffic (Figure 10). Increased visibility on the web due to the fact that marketplaces appear on the first pages of Google. However, in the USA, buyers immediately begin to search for the desired product on marketplaces, bypassing Google. In particular, Amazon has $55 \%$ of direct traffic, eBay - 66\%, AliExpress $66 \%$. In Ukraine the tendency is similar: the share of direct traffic on Prom.ua - 27\%, Rozetka - 35\%, OLX - 49\%, AliExpress - 67\% (Coleman, 2020; EVO). This traffic distribution correlates with data from Hlinenko \& Daynovskyy surveys (2018);
- available digital marketing (PPC, SEO, Social media, SEM, Email, branding);

- the existing of an individual page for service that meets the expectations of consumers of "personalized service";

- optimization of the marketplace for the mobile version. Consumers are increasing their purchases via mobile phones. In online commerce, mobile phones account for $77 \%$ of traffic and $69 \%$ of store profits (Coleman, 2020). Interestingly, consumers go to Ukrainian marketplaces from mobile phones and use a desktop to search on foreign marketplaces (Figure 11). The analysis was conducted on the TOP-10 marketplaces in October 2019.

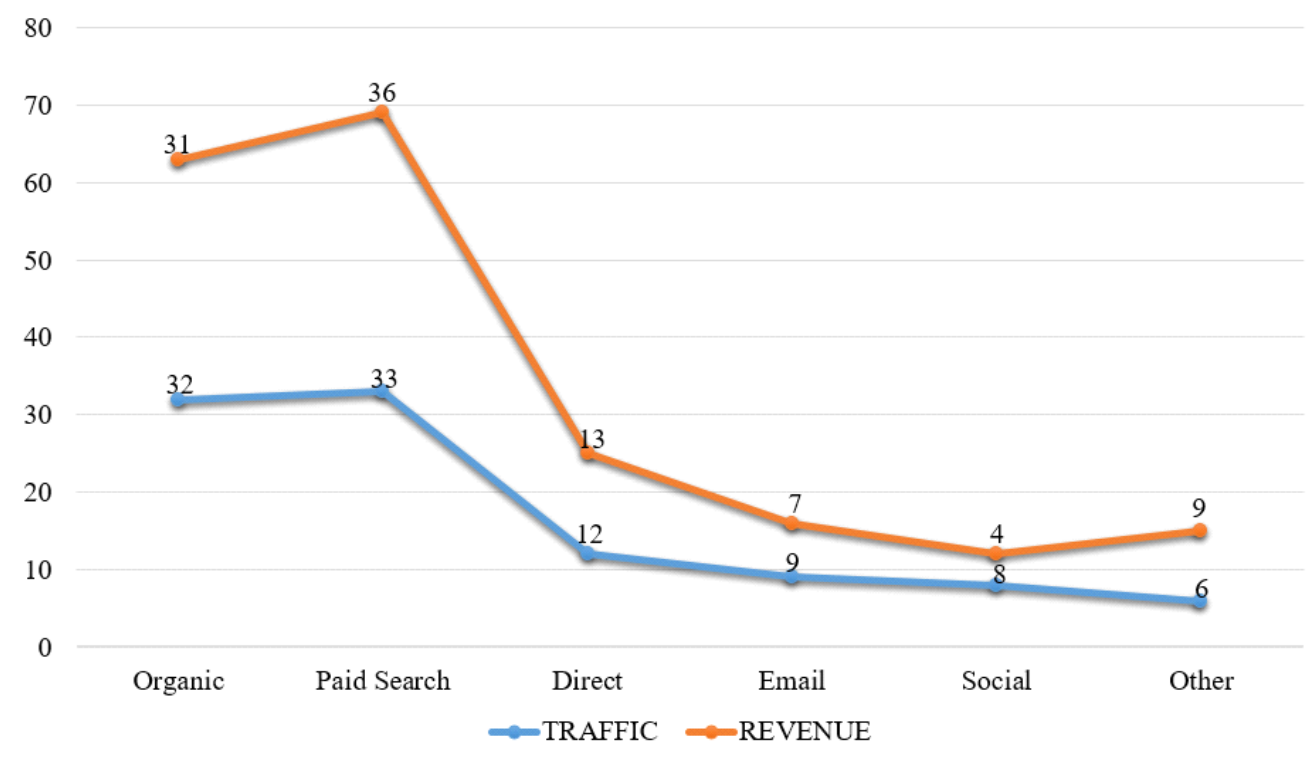

Figure 10. Sources that generate traffic and revenue 


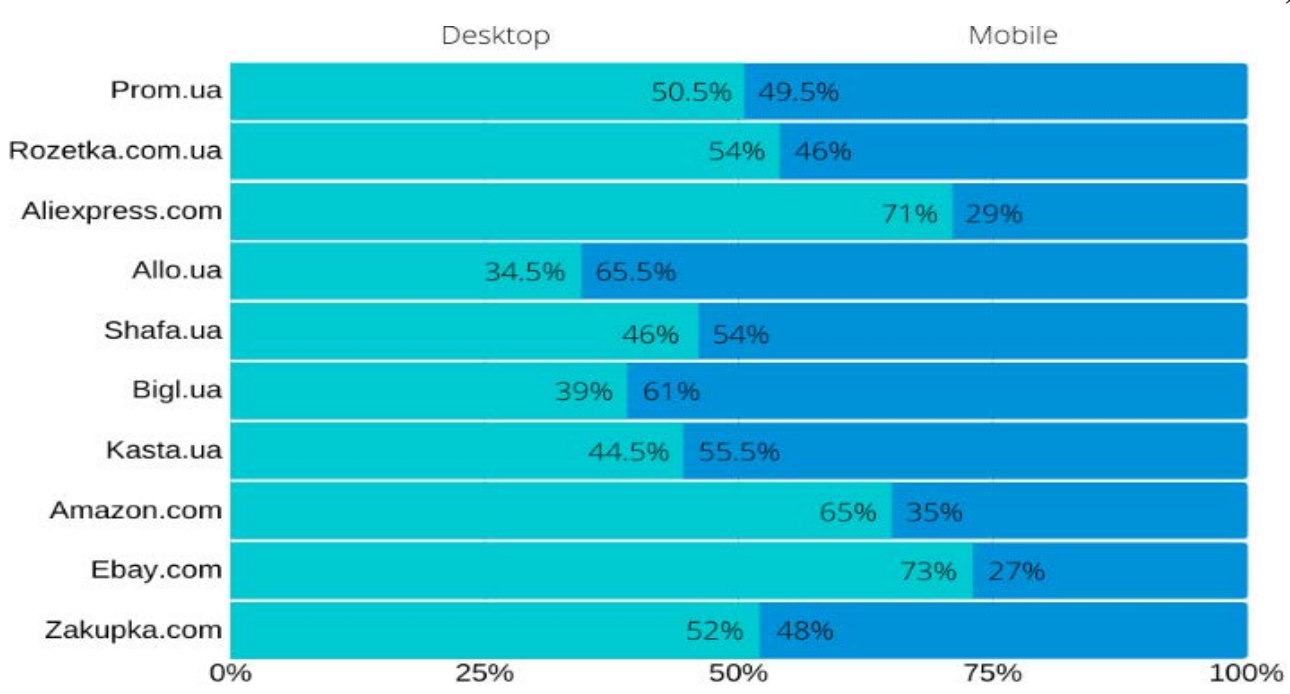

Figure 11. Exit to the marketplace

- availability of powerful analytical tools that allow to get analytics in real-time. In particular, the buyer can: see ratings, reviews, number of unique visitors, Time Spent on Site (TSS), Pages Per Visit (PPV), a share of new consumers for the period, Bounce Rate (BR), Average Order Value (AOV), Customer Retention Rate (CRR), Purchase Frequency (PF), Customer Churn Rate (CCR), Repeat Purchase Rate (RPR);

In general, the phenomenon of the marketplace can be described as "unite if you cannot compete". That is, marketplaces are universal and large-scale, and therefore grow and develop faster than single Internet projects. So we can predict that in the nearest future the vast majority of online purchases in the world will be made through marketplaces.

\section{Discussion}

The analysis allows us to understand that the vector of e-commerce development is aimed at globalization and digitalization. Using modern technologies allows not only to blur the boundaries of the market but also to use new tools for sales in the e-commerce sector, including marketplaces. The emergence of marketplaces is due to two key factors: the growing level of penetration of the Internet into the lives of consumers and the development of e-commerce. The correlation between these indicators is emphasized, as significant online activity in trade is observed in countries with a high level of the Internet penetration. Analysis of the current state of e-commerce is quite complicated because of the lack of scientific work in this area, but the use of available statistical information allows to get an idea of key processes and form a portrait of the modern consumer, and outline his personal and behavioral characteristics. The modern consumer is a young, educated person, uses mobile devices, makes online purchases from time to time, but needs recommendations, personalized, preferably "instant" service, aimed at the long search for information (combines online and offline search), avoids advertising, cares about data confidentiality and the environment.

Consideration of the dominant business models of the Internet allowed us to identify the dominance of the online store and marketplace. There are variations in the organization of marketplaces, so classification is proposed, which allows to choose the best option for sale. Analyzing the state of e-commerce outlines the major drivers of marketplace development, in particular: audience loyalty, geographical unlimitedness, organic traffic, individual seller page, optimization for the mobile version, powerful analytical tools, affordable marketing. These factors will contribute to the further development of marketplaces.

\section{Conclusion}

The purpose of this study was to identify the causes and drivers of the rapid development of marketplaces. At the beginning of the study, it was suggested that this is facilitated by a significant level of Internet penetration and the development of e-commerce. The use of statistical data (reports of leading global and Ukrainian analytical companies) revealed a direct correlation between these factors. The characteristics of the network user were outlined. This makes it possible to note that the consumer is changing under the influence of the Internet and is gradually moving to the online (especially for the active population). At the same time, the consumer wants to remain an individual consumer, needs personalized service, and digital security guarantees. The modern consumer becomes more demanding when searching for information, uses reviews, combines online and offline search, tries to maximize the choice. Therefore, the emergence of marketplaces has become a logical proposition by 
business. After all, this is an aggregate platform, the level of service which best meets the demand of the modern buyer.

The functioning of several types of marketplaces is noted, which are proposed to be classified according to four features: type, specialization, manageability, and brand, as these features are decisive for both the seller and the consumer. The analysis allows us to outline the drivers of marketplace development at the present stage. To those presented in the study, new ones will undoubtedly be added that will meet the requirements of future consumers and market conditions.

Therefore, areas of further research may include: analysis of the legal framework, information flows, the impact of social networks on traffic and sales of marketplaces and other issues that will inevitably arise, which will lead to new formats and drivers for marketplaces.

\section{References:}

Anderso, C. (2008). The Long Tail. Why the Future of Business Is Selling Less of More. Hachette Book Group. Available at: https://dl.motamem.org/long_tail_chris_anderson_motamem_org.pdf (accessed: 10, July, 2020).

Bakharev, I. (2020). How the eCommerce market has changed over the past year: AdvantShop analytics. Available at: $\quad$ https://e-pepper.ru/news/kak-pomenyalsya-ecommerce-v-2019-2020-god-analitika-advantshop.html (accessed: 18, July, 2020).

Clement, J. (2019, 5 July). Online marketplaces. Statista. Available at: https://www.statista.com/topics/4827/ online-marketplaces/ (accessed: 18, July, 2020).

Coleman, A. (2020). Intro: Data is the new oil. Available at: https://www.wolfgangdigital.com/kpi-2020/ (accessed: 19, July, 2020).

Cramer-Flood, E. (2020). Global Ecommerce 2020. Available at: https://www.emarketer.com/content/globalecommerce-2020 (accessed: 17, July, 2020).

Eurostat Statistics Explained (n.d.). Available at: https://ec.europa.eu/eurostat/statistics-explained/index.php/ Glossary:E-commerce (accessed: 15, July, 2020).

EVO (n.d.). Available at: https://evo.company/ (accessed: 10, July, 2020).

Factum Group Ukraine (FGU) (n.d.). Available at: https://factum-ua.com/ (accessed: 15, July, 2020).

Fareeha, A. (2019, December 20). 2019 ecommerce in review: U.S. online grocery sales. Available at: https://www.digitalcommerce360.com/2019/12/24/2019-ecommerce-in-review-online-grocery-sales / (accessed: 18, July, 2020).

Global E-commerce Market Ranking 2019 (2019). Available at: https://www.worldretailcongress.com/ media/ Global_ecommerce_Market_Ranking_2019_001.pdf(accessed: 17, July, 2020).

Hlinenko, L., \& Daynovskyy, Y. (2018). State-of art and prospects of development of Ukrainian electronic commerce. Marketing and Management of Innovations, vol. 1, pp. 83-102. doi:10.21272/mmi.2018.1-06

Hubber. IT-company (n.d.). Available at: https https://hubber.pro/ (accessed: 22, Juny, 2020).

Kemp, S. (2020, April, 23). Digital around the world in April 2020. Available at: https://wearesocial.com/ blog/2020/04/digital-around-the-world-in-april-2020\# (accessed: 10, July, 2020).

Lipsman, A. (2019). Global Ecommerce 2019. Available at: https://www.emarketer.com/content/globalecommerce-2019 (accessed: 17, July, 2020).

National Bank of Ukraine (n.d.). Available at: https://bank.gov.ua/ua/statistic (accessed: 18, July, 2020).

OECD (The Organisation for Economic Co-operation and Development) (n.d.). Available at: https://www.oecd.org/ iaos2018/programme/IAOS-OECD2018_Item_3-D-1-Fayyaz.pdf (accessed: 15, July, 2020).

Prosovych, O., \& Botsman, Y. (2018). Marketplace as a Digital Marketing Tool. Journal of Lviv Polytechnic National University. Series of Economics and Management Issues, vol.5(897(6)), pp.32-38. doi: 10.23939/semi2018.01.032 Sergeeva, Y. (2020). All Internet statistics for 2020 - numbers and trends in the world and in Russia. Available at: https://www.web-canape.ru/business/internet-2020-globalnaya-statistika-i-trendy/ (accessed: 15, July, 2020).

Skeldon, P. (2020, July 02). 85,000 businesses launch online shops as B2C and B2B ecommerce surge in lockdown. Available at: https://internetretailing.net/themes/85000-businesses-launch-online-shops-as-b2c-and-b2becommerce-surge-in-lockdown-21639 (accessed: 18, July, 2020).

Small business sentiment is improving. European Business Association (EBA) (2020). Available at: https://eba.com.ua/en/nastroyi-malogo-biznesu-pokrashhuyutsya/ (accessed: 18, July, 2020).

State Statistics Service of Ukraine (n.d.). Available at: https://ukrstat.org/en (accessed: 18, July, 2020).

Stevanovic, I. (2020, January 29). ECommerce Statistics \& the Industry's Vibrant Future. Available at: https://kommandotech.com/statistics/ecommerce-statistics/ (accessed: 15, July, 2020).

The Ukrainian Internet Association (UIA) (n.d.). Available at: https://inau.ua/en (accessed: 08, July, 2020).

Think Forward 2020 (2020). Available at: https://wearesocial.com/uk/thinkforward-2020 (accessed: 08, July, 2020). Tushin, V. (2020). Global development of e-Commerce: USA, China, Russia. Available at: https://new-retail.ru/ business/e_commerce/globalnoe_razvitie_e_commerce_ssha_kitay_rossiya8732/(accessed: 17, July, 2020). Ukrainian Retail Association (RAŪ) (n.d.). Available at: https://rau.ua/ (accessed: 15, July, 2020). 